\title{
INFLUENCE OF COUNSELLING ON LEARNING DIFFICULTIES IN POST-BASIC SCHOOL HISTORY CURRICULUM IN KATSINA ZONAL EDUCATION QUALITY ASSURANCE
}

\section{Yusuf Danladi Muhammad}

Federal University Dutsin-ma, Katsina State, Nigeria

Email: bethoyedeji2021@gmail.com

\section{Keywords: \\ Counseling, \\ History, \\ Curriculum, \\ Implementation, \\ Learning difficulties.}

\begin{abstract}
Abstrak
Nigeria telah mencapai tujuan lama untuk merevitalisasi serta memulihkan pengajaran pembelajaran studi sejarah di bidang sistem sekolah, dengan sengaja memanfaatkan prinsip-prinsip yang tersirat dalam desain kurikulumnya untuk merangsang karakteristik kewarganegaraan prospektif universal di antara generasi muda. Namun, adanya beberapa kesulitan dalam belajar sejarah di kalangan siswa sekolah menengah atas tampaknya membuat harapan Nigeria tersebut gagal. Oleh karena itu, penelitian ini mensurvei pengaruh layanan konseling yang diberikan oleh guru BK pada siswa untuk mengatasi kesulitan belajar sejarah pasca-sekolah dasar kurikulum 2010. Hipotesis penelitian ini adalah: i. tidak ada pengaruh yang signifikan layanan konseling terhadap penyelesaian kesulitan siswa dalam pembelajaran sejarah pasca-dasar 2010 kurikulum. ii. tidak ada pengaruh yang signifikan layanan konseling dalam mengatasi tantangan pembelajaran guru dalam menerapkan kurikulum Pasca Dasar 2010. Sekitar 380 siswa yang menawarkan sejarah, 30 guru sejarah, dan 4 sekolah Pasca-Dasar di Penjaminan Mutu Pendidikan Zona Katsina diambil secara acak untuk penelitian ini. Hasil penelitian menunjukkan pengaruh yang tidak signifikan dari layanan konseling dalam mengatasi kesulitan belajar siswa dan dalam menyelesaikan tantangan guru dalam menerapkan kurikulum sejarah Post-Basic 2010.
\end{abstract}

\begin{abstract}
Nigeria had accomplished its aged - long goal of revitalizing as well as restoring the teaching - learning of historical studies in the realm of schools system, purposely to utilize the tenets implicit in its curriculum design to stimulate universal prospective citizenship characteristics amongst generation of youths. However, the lingering existence of some difficulties in learning history among the senior secondary students seems to doom the aforementioned Nigeria's hope to failure. This study therefore, surveyed the influence of counselling services rendered by school counselling masters on students to overcome learning difficulties of Post-Basic schools 2010 history curriculum. The research hypothesizes that: $i$. there is no significant influence of counseling service on resolving students' difficulties in learning 2010 Post-Basic history curriculum. ii. there is no significant influence of counseling service on resolving teachers' instructional challenges in implementing 2010 Post-Basic curriculum. Some 380 students offering history, 30 history teachers and 4 Post-Basic schools in Katsina Zonal Education Quality Assurance were randomly sampled for the study. The findings revealed insignificant influence of counselling service in resolving students' learning difficulties and in resolving the teachers' challenges in implementing the 2010 Post-Basic history curriculum.
\end{abstract}

\section{Accepted}

Juli 2021

Published

Agustus 2021
(C)202I The Authors. Published by Institute for Research and Community Services Universitas Muhammadiyah Palangkaraya. This is Open Access article under the CC-BY-SA License (http://creativecommons.org/licenses/by-sa/4.0/).

\section{INTRODUCTION}

Issues of prospective universal citizenship among the generation of youths are accorded a great value in Nigerian education system (Uwaisu, 2017). The deterioration of citizenship ideals amongst majority of Nigerians is partly, a repercussion of laxity of such school subjects as history, Social studies and geography which are designed mainly to inculcate the school - age population the rudiments of effective citizenship, put the country a midst social vices like bribery and corruption, drug abuse and drug trafficking, child abuse, human trafficking, kidnapping, hostage taking, armed robbery, arm banditry, pipeline
4. To determine the roles of counselors in assisting history teachers resolve instructional challenges in the implementation of 2010 Post-Basic history curriculum.

\section{RESEARCH QUESTIONS}

The following research questions were formulated to be answered by the study:

I) Do counselors assist students identify the difficulties in the learning of 2010 Post-Basic history curriculum?

2) Do counselors assist students resolve the difficulties in the learning of 2010 Post-Basic history curriculum? 
3) Do counselors assist history teachers identify challenge in the implementation of 2010 PostBasic history subject - matter?

4) Do counsellors assist history teachers resolve instructional challenges in the implementation of 2010 Post-Basic history curriculum?

\section{RESEARCH HYPOTHESES}

The following research null hypotheses were formulated to be tested in the study:

I) $\mathrm{HO}_{1}$ : There is no significant influence of counseling service on resolving students' difficulties in learning 2010 Post-Basic history curriculum.

2) $\mathrm{HO}_{2}$ : There is no significant influence of counseling service on resolving teachers' instructional challenges in implementing 2010 Post-Basic history curriculum.

\section{RELATED LITERATURE}

\section{Conceptualization of Counseling}

Oguzie (2014) quoted Modo et al (2013) that Counseling is one of the educational services all that promote the effectiveness of the educational system for goals attainment and guiding learners through the learning process. Counselling for effective human development is expected to focus on cognitive, affective, psychomotor, social, occupational, spiritual and environmental behaviours (Oseiwu, 20l4). Ignou (20I I) conceives that counseling is initiated to effect a change so that individuals and organizations can utilize their potentials maximally for their own benefits and that of the society at large. Department for Education (2016) also subscribes that counseling is "an intervention that children or young people can voluntarily enter into if they want to explore, understand and overcome issues in their lives which may be causing them difficulty, distress and/or confusion". Eyo, Joshua and Esuong (2010) opined that counseling "as a programme for secondary school students are designed to address the physical, emotional, social, vocational and academic difficulties of adolescent students". From the aforementioned exposition, it should be noted that counseling in schools is a process designed assist students in tune with the goals of educational support services enshrined in the National Policy of Education (2013), namely to: facilitate the implementation of the educational policy; the attainment of policy goals and the promotion of effectiveness of educational system; and make learning experiences more meaningful for children.

\section{Concept of History}

The term 'history' is a derivation from the Greek word "hisfona", meaning what we know as a result of enquiry (Esebede, 2003). Mohammed and Muntari (2019) quoted Espie (1969) that:

History is largely the behavior of adult men - their purposes, glories, successes and failures, kindness and cruelties; it is a story of heroism, war and death, of subtle maneuvering amongst twice, foolish and often ruthless men and women; the quest for and exercise of power are recurrent themes, as is the long and complex tale of man's attempt to conquer his environment; man's beliefs and length she has been prepared to advance them, are a major strand.

Ihenetu (2013) posited that history is about the beginning, the problems, the challenges, the people and the culture of a people. It poses challenges to the future in terms of aspirations, desired value system and soon. History therefore, studies the cultural successions of human generations with in time and space. And by this, it provides solid basis for the promotion as well as development of moral values and virtues which further embellish character formation amongst generations of Nigerian youths (Mohammed and Mutari, 2019).

\section{Learning Difficulties Resulted from Misconceptions of History Curriculum}

Students in Nigerian Post-Basic schools have for long been harbouring some misconceptions about history that affect their achievements in the discipline. Some of these misconceptions include such notions that history is very vast, it involves lot of memory tasks, its lessons are understood by exceptionally brainy students who possess good command in English language, that copying the lengthy lesson note is often boring, that history often requires students to read extra miles to succeed in examination, that majority of history educators are task - oriented academically, unfriendly and approachable to students.

Although, Federal Government of Nigeria had championed the renaissance of history epistemological activities in Post-Basic school system purposely to revitalize and restore an active universal citizenship amongst Nigerian youths, the above misconceptions will form a constraint that will have adversely affected the students' learning.

An analytic study of aforementioned misconceptions reflects the existence of abnormalities in some components of history classroom instruction. In the first place, the notion that "history is very vast" presupposes that most teachers do not carefully select appropriate learning experiences to ensure students understanding of historical studies. Mohammed (2016) quoted Espie (1989) that the content structures in history are very vast. Therefore, teachers should resort to idea of content selection to bring about effective teaching of history in Post-Basic schools. However, a survey of the implementation of the prospects of ICT in historical studies reported that very few Post-Basic schools do possess the copy of 2010 history curriculum, while majority of teachers use either textbooks or examination syllabus for selecting learning experiences (Mohammed, et al 2018). Indeed, this justifies the reason for the vast content because the ideal bases of curriculum selection have been corrupted by most history educators. 
Similarly, the idea that history is a package of memory tasks, depicts, from experts view point that history educator hold on to using traditional teaching strategies which are dangerous to students effective understanding of history. FGN (2019) has cautioned history teachers of using the traditional teaching methods because they task the students with memorization of dates, names and events at the expense of understanding. Moreover, the new PostBasic school history curriculum mandates teachers to utilize Modern Teaching Approach (MTA) in classroom activities because it provides for the use of activity - based teaching methods like debating, quizzing, role playing, excursion / field trip, dramatization, assessment and project methods which put learners at the centre of all classroom engagements.

Furthermore, the idea that history lessons are understood by exceptionally brainy students who have a good command in English language conveys teachers' lackadaisity of the use of curriculum resource materials especially, the audio - visual materials. Mohammed (2016) quoted Espie (1989) that visual curriculum materials are instrumental to effective and purposeful teaching of history subject matter. The audio - visual materials make narration of historical events real and lively to students. Teaching history without the use of audio - visuals will best be described as the abstract narration of historical events that will scare learners.

Added to the above, history educators mostly utilize heavy / big vocabularies, figurative expressions and other language expressions to impress the students during interactive sessions, explanation and discussions of historical concepts and events. This has a scaring effect on the students learning the subject matter of history in Katsina state Post-Basic schools.

Finally, evaluating history instruction in Post-Basic schools follows the traditional pattern of using some terms like critically examine, discuss, justify, elucidate, analyze, assess, judge etc and twisty examination questions with higher difficulty index. In a nut shell, evaluation strategy supposes to cater for the average, above average and blow average. This abnormality in the evaluation of history classrooms contribute to students' phobia towards history.

Therefore, the combination of those abnormalities that feature apparently in history classroom instructions mainly due to teachers' academic as well as professional inadequacies has culminated in students' difficulties to learning the subject matter. Hence, this situation requires all school managements to capitalize on assets implicit in educational counseling service being rendered by their guidance and counseling units with a view to helping students resolve their learning difficulties in new 2010 PostBasic history curriculum.

\section{Methodology}

The descriptive survey design was adopted for the study. A descriptive survey design is concerned with describing events as they are without a manipulation of what caused the event or what is being observed.

All history teachers and the students offering history in public Post-Basic schools in Katsina Zonal Education Quality Assurance, Katsina state formed the population of the study. Four public Post-Basic schools that offer history as a subject were purposively sampled for the research. A total of thirty (30) history teachers who are teaching in the four Post-Basic schools were purposively sampled for the research and this was because the number was manageable. And 380 Post-Basic School history students were randomly sampled for the research. A proportionate sampling technique was used when selecting the students sample from Post-Basic School I, II and III. This was meant to ensure a proportional representation of all classes in the sample. The sample size of the 380 was arrived at using a table of sample determination prepared by Morgan and Kreycie (I97I).

This research was carried out using two different questionnaire instruments. The first is a 14 items questionnaire instrument titled 'History Teachers' Instructional Difficulties Identifying Scale" (HITIDIS). The 14 item instrument was divided into three (3) sections; $A, B$, and $C$.

The second was a 13 items questionnaire instrument titled 'History Students' Learning Difficulties Identification Scale (HISLEDIS). The 13 item instrument was divided into three (3) sections; A, B and $\mathrm{C}$.

The instruments were validated by a lecturer in the department of Educational Foundations, Federal University Dutsin-Ma, Katsina state to determine their suitability, reliability co-efficient of the first instrument .793. And that of second instrument .724, were obtained at the pilot study, using test-retest method. The items of the instruments are mounted beside a five-point scale ranging "Strongly Agree" $(A=1)$; "Agree" $(S A=2)$; "Disagree" $(D=3)$; "Strongly Disagree" (SD = 4).

Data were collected to examine influence of counseling services on students to resolve learning difficulties and the teachers to overcome their challenges in implementing Post-Basic history. Simple percentage was used to answer the research questions raised and linear regression statistics was used to test the hypotheses formulated.

The sampled schools' managements were informed of the study and permitted the concerned teachers and students to participate in the research. Members of the research team went round the schools during school hours, for the administration of questionnaires on the sampled teachers and students, in November, 20019. And the questionnaires were filled with anonymity.

Results 


\section{Role of Counselors in Assisting Students Identify the Difficulties in Learning Post-Basic History}

The findings on the role of counselors in helping students to identify their difficulties in learning PostBasic school history curriculum is summarized in table I

Table I: Role of Counselors in Assisting Students to Identify Difficulties in Learning Post-Basic History

\begin{tabular}{|c|c|c|c|c|c|c|c|c|c|c|}
\hline \multirow{3}{*}{$\begin{array}{ll}\text { S/N } & \\
& \text { ITEMS }\end{array}$} & \multicolumn{10}{|c|}{ RESPONSES } \\
\hline & \multicolumn{2}{|l|}{ SA } & \multicolumn{2}{|l|}{ A } & \multicolumn{2}{|l|}{ SD } & \multicolumn{2}{|l|}{ D } & \multicolumn{2}{|c|}{ TOTAL } \\
\hline & $\mathbf{N}$ & $\%$ & $\mathbf{N}$ & $\%$ & $\mathbf{N}$ & $\%$ & $\mathbf{N}$ & $\%$ & $\mathbf{N}$ & $\%$ \\
\hline $\begin{array}{l}\text { The vast nature of } \\
\text { history subject - matter } \\
\text { frightens the students, } \\
\text { especially } \\
\text { the beginners }\end{array}$ & $\begin{array}{l}1 \\
4 \\
5\end{array}$ & $\begin{array}{l}38 \\
16\end{array}$ & $\begin{array}{l}38 \\
.1 \\
6\end{array}$ & 128 & $\begin{array}{l}33 . \\
68\end{array}$ & $\begin{array}{l}7 \\
2\end{array}$ & $\begin{array}{l}1 \\
8 \\
9\end{array}$ & $\begin{array}{l}3 \\
5\end{array}$ & $\begin{array}{l}3 \\
8 \\
0\end{array}$ & 100 \\
\hline $\begin{array}{l}\text { The scarcity of relevant } \\
\text { textbooks in the school } \\
\text { library limits my } \\
\text { academic performance } \\
\text { in history. }\end{array}$ & $\begin{array}{l}1 \\
3 \\
2\end{array}$ & $\begin{array}{l}34 \\
73\end{array}$ & 84 & $\begin{array}{l}22.1 \\
1\end{array}$ & 92 & $\begin{array}{l}2 \\
4 . \\
2 \\
1\end{array}$ & $\begin{array}{l}7 \\
2\end{array}$ & $\begin{array}{l}1 \\
8 . \\
9 \\
5\end{array}$ & $\begin{array}{l}3 \\
8 \\
0\end{array}$ & 100 \\
\hline $\begin{array}{l}\text { The teachers' } \\
\text { unfriendly and } \\
\text { unapproachable } \\
\text { attitudes add up } \\
\text { to my challenges in } \\
\text { learning history. }\end{array}$ & $\begin{array}{l}9 \\
6\end{array}$ & $\begin{array}{l}25 . \\
26\end{array}$ & $\begin{array}{l}10 \\
1\end{array}$ & $\begin{array}{l}26.5 \\
8\end{array}$ & $\begin{array}{l}11 \\
0\end{array}$ & $\begin{array}{l}2 \\
8 . \\
9 \\
5\end{array}$ & $\begin{array}{l}7 \\
3\end{array}$ & $\begin{array}{l}1 \\
9 . \\
2 \\
1\end{array}$ & $\begin{array}{l}3 \\
8 \\
0\end{array}$ & 100 \\
\hline $\begin{array}{l}\text { Poor commands of } \\
\text { English language } \\
\text { seriously affect my } \\
\text { understanding } \\
\text { of history lessons. }\end{array}$ & $\begin{array}{l}1 \\
6 \\
4\end{array}$ & $\begin{array}{l}43 . \\
16\end{array}$ & 95 & 25 & 58 & $\begin{array}{l}1 \\
5 . \\
2 \\
7\end{array}$ & $\begin{array}{l}6 \\
3\end{array}$ & $\begin{array}{l}1 \\
6 . \\
5 \\
7\end{array}$ & $\begin{array}{l}3 \\
8 \\
0\end{array}$ & 100 \\
\hline $\begin{array}{l}\text { The need to memorize } \\
\text { some name, } \\
\text { dates, facts and figures } \\
\text { in historical } \\
\text { events hinders my } \\
\text { achievement in history. }\end{array}$ & $\begin{array}{l}1 \\
0 \\
2\end{array}$ & $\begin{array}{l}26 . \\
84\end{array}$ & 64 & $\begin{array}{l}16.8 \\
4\end{array}$ & $\begin{array}{l}13 \\
2\end{array}$ & $\begin{array}{l}3 \\
4 . \\
7 \\
4\end{array}$ & $\begin{array}{l}8 \\
2\end{array}$ & $\begin{array}{l}2 \\
1 . \\
5 \\
8\end{array}$ & $\begin{array}{l}3 \\
8 \\
0\end{array}$ & 100 \\
\hline
\end{tabular}

Table I presents percentage of responses of influence of counselling service rendered to identify students with difficulties in learning Post-Basic history curriculum in Katsina Zonal Education Quality Assurance. It shows that $71.84 \%$ of the students agree that vast nature of history curriculum affects their performance while $28.15 \%$ of them did not agree. Also $56.84 \%$ of the students agree that scarcity of relevant history textbooks in the school library limits their academic performance whereas $43.16 \%$ of them did not agree; $51.84 \%$ of the students agree that teachers' unfriendly attitudes add up to their difficulties of learning history while $48.16 \%$ of them did not agree; $68.16 \%$ of the students agree that poor command of English language affects their understanding of history lessons whereas $31.84 \%$ of them did not agree. Lastly, $43.68 \%$ of the students agree that memorization of dates and names hinder their achievement in history while $56.32 \%$ did not agree.

Role of Counselors in Assisting Students to Resolve Identified Difficulties in Learning PostBasic History Curriculum

The findings on the role of counselors in helping students to resolve the identified difficulties in learning Post-Basic school history curriculum is summarized in table 2.
Table 2: Role of Counselors in Assisting Students to Resolve Identified Difficulties in Learning Post-Basic History Curriculum

Table 4.2 above presents percentage of responses of influence of counselor service rendered to assist students resolve the difficulties in learning Post-Basic history curriculum in Katsina Zonal Education Quality Assurance. It reveals that $49.73 \%$ of the students agreed that counselors assist them in identifying their areas of interest and interest of history while $50.26 \%$ of them did not agree; $54.74 \%$ of the students agreed that counselors assist in placing them into various subject interests to enhance their performance while $45.26 \%$ of them did not agree; $48.68 \%$ of the students agreed that counselors refer them to group discussion for the study of history whereas $51.31 \%$ of them did not agree; $50.26 \%$ of the students agreed that counselors orient students on the use of school library and its materials for the their success in history learning while $49.74 \%$ of them did not agree; 52.63 of the students agreed that counselors suggest good reading styles to help them deal with difficulties in learning history whereas $47.37 \%$ of them did not agree. Also $68.42 \%$ of the students agreed that counselor suggest alternative sources of getting

\begin{tabular}{|c|c|c|c|c|c|c|c|c|c|c|}
\hline \multirow[t]{3}{*}{ ITEMS } & \multicolumn{10}{|c|}{ RESPONSES } \\
\hline & \multicolumn{2}{|r|}{ SA } & \multicolumn{2}{|c|}{ A } & \multicolumn{2}{|c|}{ SD } & \multicolumn{3}{|c|}{$\mathrm{D}$} & \multirow{2}{*}{$\begin{array}{l}\text { TOTA } \\
\text { L } \\
\%\end{array}$} \\
\hline & $\mathbf{N}$ & $\%$ & $\mathbf{N}$ & $\%$ & $\mathbf{N}$ & $\%$ & $\mathbf{N}$ & $\%$ & $\mathbf{N}$ & \\
\hline $\begin{array}{l}\text { I.Counsellors assists students } \\
\text { identify their } \\
\text { subject area of interest and } \\
\text { interest in history. }\end{array}$ & 87 & $\begin{array}{l}22 . \\
89\end{array}$ & $\begin{array}{l}1 \\
0 \\
2\end{array}$ & $\begin{array}{l}26 \\
.8 \\
4\end{array}$ & $\begin{array}{l}8 \\
5\end{array}$ & $\begin{array}{l}2 \\
2 \\
3 \\
3 \\
7\end{array}$ & $\begin{array}{l}1 \\
0 \\
6\end{array}$ & $\begin{array}{l}2 \\
7 \\
8 \\
8 \\
9\end{array}$ & $\begin{array}{l}3 \\
8 \\
0\end{array}$ & 100 \\
\hline $\begin{array}{l}\text { 2. Counsellors help place } \\
\text { students into various } \\
\text { subject interest areas to } \\
\text { enhance their } \\
\text { performance. }\end{array}$ & $\begin{array}{l}12 \\
2\end{array}$ & $\begin{array}{l}32 . \\
11\end{array}$ & $\begin{array}{l}8 \\
6\end{array}$ & $\begin{array}{l}22 \\
.6 \\
3\end{array}$ & $\begin{array}{l}9 \\
9\end{array}$ & $\begin{array}{l}2 \\
6 \\
0 \\
0 \\
5\end{array}$ & $\begin{array}{l}7 \\
3\end{array}$ & $\begin{array}{l} \\
9 \\
2 \\
1\end{array}$ & $\begin{array}{l}3 \\
8 \\
0\end{array}$ & 100 \\
\hline $\begin{array}{l}\text { 3. Counsellors refer the } \\
\text { students to the use of } \\
\text { group discussion for the study } \\
\text { of history in } \\
\text { order to benefit from group } \\
\text { dynamics. }\end{array}$ & 89 & $\begin{array}{l}23 . \\
42\end{array}$ & $\begin{array}{l}9 \\
6\end{array}$ & $\begin{array}{l}25 \\
.2 \\
6\end{array}$ & $\begin{array}{l}1 \\
0 \\
9\end{array}$ & $\begin{array}{l}2 \\
8 \\
6 \\
6 \\
8\end{array}$ & $\begin{array}{l}8 \\
6\end{array}$ & $\begin{array}{l}2 \\
2 \\
. \\
6 \\
3\end{array}$ & $\begin{array}{l}3 \\
8 \\
0\end{array}$ & 100 \\
\hline $\begin{array}{l}\text { 4. Counsellors orient students } \\
\text { on how to use } \\
\text { school library and its materials } \\
\text { for their } \\
\text { success in history. }\end{array}$ & 90 & $\begin{array}{l}23 . \\
68\end{array}$ & $\begin{array}{l}1 \\
0 \\
1\end{array}$ & $\begin{array}{l}26 \\
.5 \\
8\end{array}$ & $\begin{array}{l}9 \\
7\end{array}$ & $\begin{array}{l}2 \\
5 \\
5 \\
5 \\
3 \\
\end{array}$ & $\begin{array}{l}9 \\
2\end{array}$ & $\begin{array}{l}2 \\
4 \\
2 \\
2 \\
1\end{array}$ & $\begin{array}{l}3 \\
8 \\
0\end{array}$ & 100 \\
\hline $\begin{array}{l}\text { 5.Counsellors suggest a very } \\
\text { good reading } \\
\text { style / pattern to enable } \\
\text { students get rid of } \\
\text { the fear of vast history } \\
\text { content. }\end{array}$ & $\begin{array}{l}10 \\
2\end{array}$ & $\begin{array}{l}26 . \\
84\end{array}$ & $\begin{array}{l}9 \\
8\end{array}$ & $\begin{array}{l}25 \\
.7 \\
9\end{array}$ & $\begin{array}{l}9 \\
4\end{array}$ & $\begin{array}{l}2 \\
4 \\
7 \\
7\end{array}$ & $\begin{array}{l}8 \\
6\end{array}$ & $\begin{array}{l}2 \\
2 \\
. \\
6 \\
3\end{array}$ & $\begin{array}{l}3 \\
8 \\
0\end{array}$ & 100 \\
\hline $\begin{array}{l}\text { 6. Counsellors suggest } \\
\text { alternative sources } \\
\text { via which students get } \\
\text { relevant history } \\
\text { textbooks to enhance their } \\
\text { academic } \\
\text { growth in the subject - matter. }\end{array}$ & $\begin{array}{l}16 \\
3\end{array}$ & $\begin{array}{l}42 . \\
89\end{array}$ & $\begin{array}{l}9 \\
7\end{array}$ & \begin{tabular}{|l|}
25 \\
.5 \\
3
\end{tabular} & $\begin{array}{l}5 \\
6\end{array}$ & $\begin{array}{l}1 \\
4 \\
\vdots \\
7\end{array}$ & $\begin{array}{l}6 \\
4\end{array}$ & $\begin{array}{l}1 \\
6 \\
8 \\
8 \\
4\end{array}$ & $\begin{array}{l}3 \\
8 \\
0\end{array}$ & 100 \\
\hline $\begin{array}{l}\text { 7.Counsellors suggest very } \\
\text { good self- } \\
\text { study techniques as well as } \\
\text { English } \\
\text { textbooks that enable } \\
\text { students improve } \\
\text { their commands in the } \\
\text { language. }\end{array}$ & 89 & $\begin{array}{l}23 \\
42\end{array}$ & $\begin{array}{l}9 \\
8\end{array}$ & $\begin{array}{l}25 \\
.7 \\
9\end{array}$ & $\begin{array}{l}1 \\
1 \\
4\end{array}$ & & \begin{tabular}{|l|}
7 \\
9
\end{tabular} & $\begin{array}{l}2 \\
0 \\
7 \\
7 \\
9\end{array}$ & \begin{tabular}{|l|}
3 \\
8 \\
0 \\
\end{tabular} & 100 \\
\hline $\begin{array}{l}\text { 8. Counsellors guide the } \\
\text { students to study } \\
\text { their teachers in order to } \\
\text { understand their } \\
\text { personality, moods and } \\
\text { attitudes being the } \\
\text { variables cementing the } \\
\text { teacher - students' } \\
\text { relationship. }\end{array}$ & 64 & $\begin{array}{l}16 . \\
84\end{array}$ & $\begin{array}{l}5 \\
3\end{array}$ & $\begin{array}{l}13 \\
.9 \\
5\end{array}$ & $\begin{array}{l}1 \\
2 \\
3\end{array}$ & $\begin{array}{l}3 \\
2 \\
3 \\
3\end{array}$ & \begin{tabular}{|l|}
1 \\
4 \\
0
\end{tabular} & $\begin{array}{l}3 \\
6 \\
8 \\
8 \\
4\end{array}$ & \begin{tabular}{|l|}
3 \\
8 \\
0 \\
1 \\
0 \\
0
\end{tabular} & \\
\hline $\begin{array}{l}\text { 9. Counsellors suggest a very } \\
\text { good reading } \\
\text { style that enable students } \\
\text { understand very } \\
\text { easily the historical facts like } \\
\text { names, } \\
\text { dates and figures. }\end{array}$ & $\begin{array}{l}12 \\
6\end{array}$ & $\begin{array}{l}33 . \\
16\end{array}$ & $\begin{array}{l}6 \\
9\end{array}$ & $\begin{array}{l}18 \\
.1 \\
6\end{array}$ & $\begin{array}{l}9 \\
8\end{array}$ & $\begin{array}{l}2 \\
5 \\
5 \\
7 \\
9\end{array}$ & \begin{tabular}{|l|}
8 \\
7
\end{tabular} & $\begin{array}{l}2 \\
2 \\
. \\
8 \\
9\end{array}$ & \begin{tabular}{|l|}
3 \\
8 \\
0
\end{tabular} & 100 \\
\hline
\end{tabular}


relevant history textbooks to enhance their academic growth whereas $31.58 \%$ of them did not agree; $49.21 \%$ of the students agreed that counselor suggest good self - study techniques as well as English textbooks that enable them improve their command in the language while $50.79 \%$ of them did not agree; $30.79 \%$ of the students agreed that counselors guide them to study their teachers purposely to understand their personalities, attitudes and moods while $69.21 \%$ of them did not agree. Lastly, 5I.32\% of the students agreed that counselors suggest good reading style to enable them understand historical concepts and facts at relative ease whereas $48.68 \%$ of them did not agree. Role of Counselors in Assisting Teachers to Identify Challenges of Implementing Post-Basic History Curriculum

The finding on the role of counselors in helping teachers to identify challenges of implementing PostBasic school history curriculum is summarized in table 3.

Table 3: Role of Counselors in Assisting Teachers to Identify Challenges of Implementing Post-Basic History Curriculum

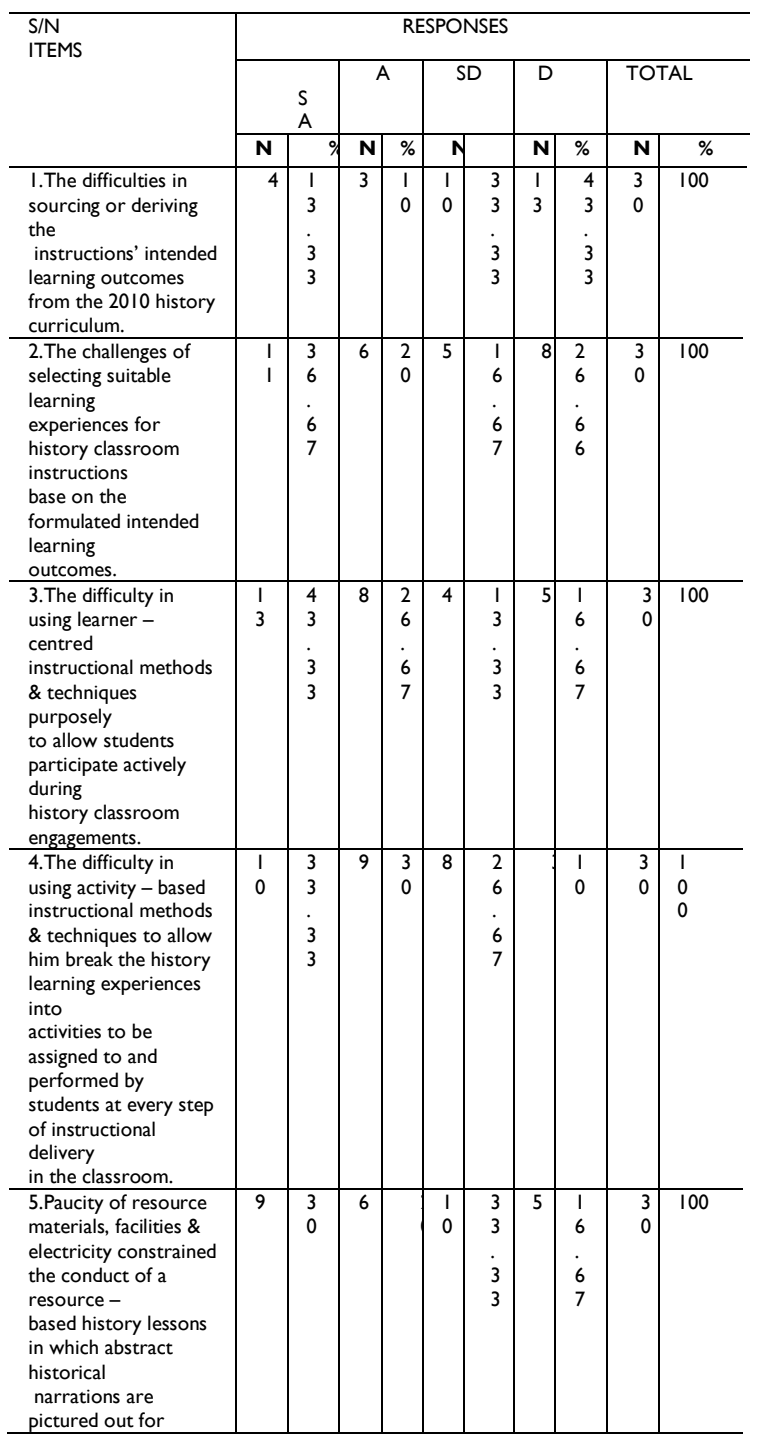

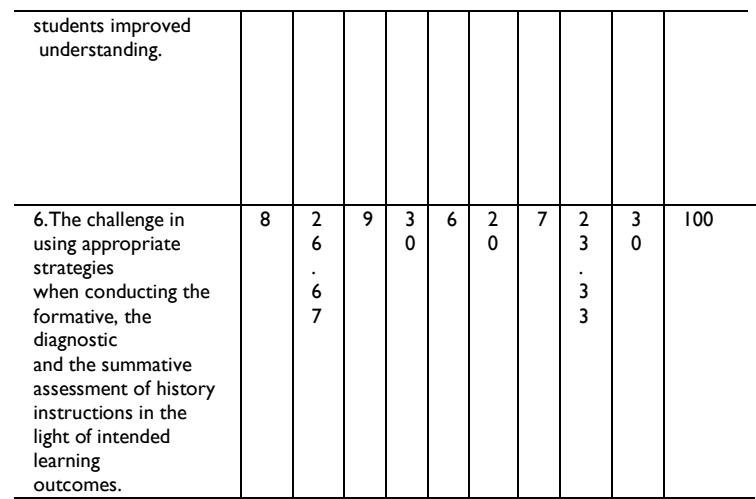

Table 4.3 above presents percentage of responses of influence of counselling service rendered to identify teachers with challenges in implementing Post-Basic history curriculum in Katsina Zonal Education Quality Assurance. It reports that $2333 \%$ of the teachers experienced some difficulties in sourcing or deriving intended learning outcomes from 2010 history curriculum for effective implementation while $7667 \%$ of them did not witness such difficulties; $56.67 \%$ of the teachers found it challenging to select suitable learning experiences for history lesson based on the instructional objectives formulated whereas $43.33 \%$ of them did not face the challenge; $70 \%$ of the teachers face the difficulties surrounding the use of learner centred instructional methods and techniques to allow students partake in history classroom engagements while $30 \%$ of them did not find it difficult. Also $63.33 \%$ of the teachers face the difficulty of using activity base instructional methods and techniques for assigning students with gainful academic activities during history classroom encounters whereas $36.67 \%$ of them did not face the difficulty; $50 \%$ of the teachers were constrained by paucity of materials, facilities and electricity for conducting a resource - base history lesson while $50 \%$ of them did not experience the constrain; $56.67 \%$ of the teachers found it challenging to select and use apt strategies for the formative , diagnostic and summative evaluation of history instructions whereas $43.33 \%$ of them did not face the difficulty.

Role of Counselors in Assisting Teachers to Resolve the Identified Challenges of Implementing Post-Basic History Curriculum The finding on the role of counselors in helping teachers to resolve the identified challenges of implementing Post-Basic school history curriculum is summarized in table 4.

Table 4: Role of Counselors in Assisting Teachers Resolve the Identified Challenges of Implementing Post-Basic History Curriculum

\begin{tabular}{|c|c|c|c|c|c|c|c|c|c|c|c|}
\hline \multirow[t]{3}{*}{$\mathrm{S} / \mathrm{N}$} & \multirow[t]{3}{*}{ ITEMS } & \multicolumn{10}{|c|}{ RESPONSES } \\
\hline & & \multicolumn{2}{|c|}{ SA } & \multicolumn{2}{|r|}{ A } & \multicolumn{2}{|r|}{$S$} & \multicolumn{2}{|c|}{ D } & \multicolumn{2}{|c|}{ Total } \\
\hline & & $\mathbf{N}$ & $\%$ & $\mathbf{N}$ & $\%$ & $\mathbf{N}$ & $\%$ & $\mathbf{N}$ & $\%$ & $\mathbf{N}$ & $\%$ \\
\hline
\end{tabular}




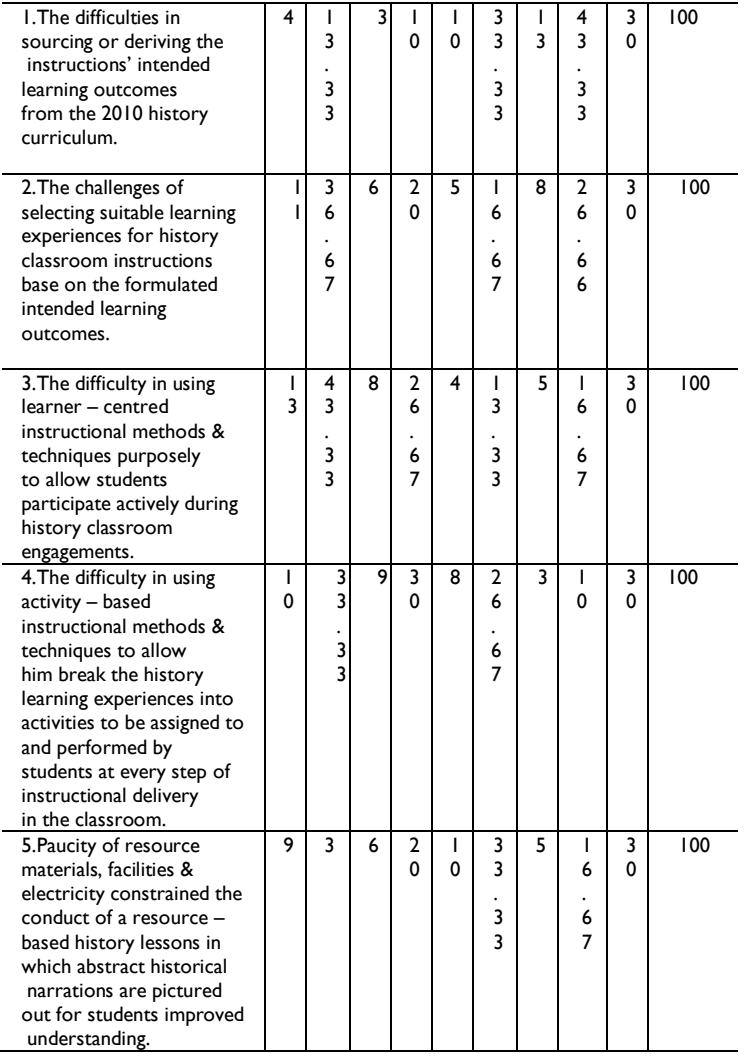

Table 4 above presents percentage of responses of influence of counselling service rendered to assist teachers resolve their challenges in implementing PostBasic history curriculum in Katsina Zonal Education Quality Assurance. It indicates that $43.33 \%$ of the teachers agreed that counselors play a keen role to them overcome the difficulties in sourcing or deriving the instructional objectives from the 2010 Post-Basic history curriculum while $56.67 \%$ of them did not agree; $53.33 \%$ of the teachers agreed that counselors help them in resolving the challenges of selecting relevant learning experiences for history lessons while $46.67 \%$ of them did not agree; $40 \%$ of the teachers agreed that counselors assist them overcome the challenges involved in using learner - centred instructional methods and techniques for students active participation in history lessons whereas $60 \%$ of them did not agree. Also $46.67 \%$ of the teachers agreed that counselors help them in resolving the challenges involved in using activity - based instructional methods and techniques to enable students be assigned with gainful academic tasks during history lessons while $53.33 \%$ of them did not agree; 56.67 of the teachers agreed that counselors assist them in resolving the challenges surrounding the paucity of materials, facilities and resources by suggesting the use of locally available once for the conduct of resource - based history lessons while $43.33 \%$ did not agree; $46.67 \%$ of the teachers agreed that counselors help them to resolve the challenges of selecting and utilizing apt strategies of conducting the formative, diagnostic and summative evaluation of history lessons while $53.33 \%$ of them did not agree.
Influence of Counseling Services on Students' Difficulties of Associated with Learning of PostBasic History Curriculum

The finding on the influence of counseling services in helping students to resolve difficulties associated with learning of Post-Basic school history curriculum is summarized in table 5 .

Table 5: Linear Regression of Students' Difficulties in Learning 2010 Post-Basic History Curriculum Consequent to Counseling Services.

$\mathbf{R}=\mathbf{0 . 0 8}$ I Adjusted $\mathbf{R}$ Square $=0.004$ $R^{2}=0.007$ Standard Error $=1.03$

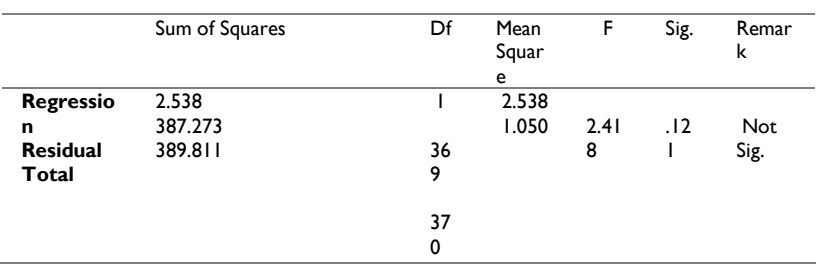

Table 4.5 above proves that the coefficient of determination (Adjusted R2) $=0.004$, which gives the proportion of variance to be $0.4 \%$. This indicates that about $0.4 \%$ of the entire changes in students' abilities to resolve their difficulties in learning 2010 Post-Basic history curriculum is determined by services rendered by school counseling master. The influence of counseling upon students' difficulties in learning senior secondary 2010 history curriculum in Katsina Zonal Education Quality Assurance is shown to be insignificant $(F(I, 369)=2.4 I 8 ; P>0.05)$. Therefore, it could be concluded that about $0.4 \%$ of changes in students' abilities to resolve their learning difficulties is accounted for by the services of school counseling masters and this percentage is highly insignificant. This is in line with Alkammawa (20I7) that parents now tell their children not to read history. The parental distaste of the subject matter weakens the influence of counseling service on students to resolve their difficulties in learning the 2010 Post-Basic school curriculum. This further shown that the school counseling masters are not doing very well with regards to effective counseling service. Therefore, the $\mathrm{Hol}$ at 0.05 significant levels is accepted.

\section{Influence of Counseling Services on Teachers' Challenges of Implementing of Post-Basic History Curriculum}

The finding on the influence of counseling services in helping teachers to resolve challenges of implementing Post-Basic school history curriculum is summarized in table 6.

Table 6: Linear Regression of Teachers' Instructional Challenges of Implementing 2010 Post-Basic History Curriculum Consequent to Counseling Service. 
$\mathbf{R}=\mathbf{0 . 0 2 8}$ Adjusted $\mathbf{R}$ Square $=0.0 \mathrm{I} \mathrm{I}$

$R^{2}=0.001$ Standard Error $=0.78 I$

\begin{tabular}{|c|c|c|c|c|c|c|}
\hline & $\begin{array}{l}\text { Sum of } \\
\text { Squares }\end{array}$ & Df & $\begin{array}{l}\text { Mean } \\
\text { Square }\end{array}$ & $\mathrm{F}$ & Sig. & Remark \\
\hline Regression & .041 & 1 & .041 & & & \\
\hline $\begin{array}{l}\text { Residual } \\
\text { Total }\end{array}$ & 53.614 & $\begin{array}{l}88 \\
89\end{array}$ & .609 & 0.067 & .796 & $\begin{array}{l}\text { Not } \\
\text { Sig. }\end{array}$ \\
\hline
\end{tabular}

53.655

\section{$(\mathrm{P}>0.05)$}

Table 6 above revealed that the coefficient of determination (Adjusted R2) $=0.01 \mathrm{l}$, which yielded a proportion of variance of $1.1 \%$. This indicates that about $1.1 \%$ of the total changes in teachers' capability to resolve instructional challenges hindering the effective and purposeful implementation of the 2010 Post-Basic history curriculum is determined by the effectiveness of counseling services rendered by the school counseling masters. The influence of counseling upon teachers' difficulties in implementing the PostBasic 2010 history curriculum in Katsina Zonal Education Quality Assurance is reported to be insignificant $(F(I, 88)=0.067 ; P>0.05)$. Therefore, it is concluded that about $1.1 \%$ of the total changes in teachers' abilities to resolve their difficulties or barriers to effective implementation of 2010 senior secondary history curriculum is resulted by the services of school counseling masters and this percentage is highly insignificant. This further implies that history educators in Post-Basic schools do not relate with the school counseling masters who are always render effective counseling services for teachers to accomplish efficacy in curriculum implementation. Therefore, the $\mathrm{Ho} 2$ at 0.05 significant levels is accepted.

\section{Discussion and Conclusion}

The findings of this study indicates that (Adjusted $R^{2}$ ) $=0.004$, which gives the proportion of variance to be $0.4 \%$, meaning there is no significant influence of counseling service on resolving students' difficulties in learning 2010 Post-Basic history curriculum; (Adjusted $R^{2}$ ) $=0.01 \mathrm{I}$, which yielded a proportion of variance of $1.1 \%$, There is no significant influence of counseling service on resolving teachers' instructional challenges in implementing 2010 Post-Basic history curriculum. This is in line with Alkammawa (2017) that parents now tell their children not to read history. The parental distaste of the subject matter weakens the influence of counseling service on students to resolve their difficulties in learning the 2010 Post-Basic school curriculum.

The above findings imply that counseling services rendered by the school counseling master does not have a significant influence upon students' abilities to resolve the difficulties in learning 2010 Post-Basic history curriculum in Katsina Zonal Education Quality
Assurance, because about $0.4 \%$ of the entire changes in students' abilities to resolve their difficulties in learning 2010 Post-Basic history curriculum is determined by services rendered by school counseling master. The findings also shown that there is no significant influence of counseling service on teachers' abilities to resolve the instructional challenges in implementing 2010 Post-Basic history curriculum, because about $1.1 \%$ of the total changes in teachers' abilities to resolve their difficulties or rather barriers to effective implementation of 2010 Post-Basic history curriculum are resulted by the services of school counseling masters and this percentage is highly insignificant.

This above happened because almost all counseling units in Post-Basic schools are not being handled by professionally trained counselors. Therefore, the task of counseling students as well as the teachers out of their respective difficulties is now being handled by Para - counselors (i.e. professionally trained teachers who are assigned by school management to counsel students).

Also most of the Para - counselors are professional teachers who are employed to teach their subject of specialty but school managements assigns them to additional duty of the school counseling masters, and this why the counseling masters do not have ample time to attend to students complaints. Most often students visit the school counseling office with their complaints but they usually meet the counselor absent. Furthermore, the school counseling office has failed very woefully to establish and sustain a cordial relationship with history teachers which would enable them know some of the challenges impinging upon efficient implementation of 2010 Post-Basic history curriculum purposely to contribute their best towards helping teachers overcome them. This is perhaps, reason why school counseling unit failed to function effectively to enable educators and the students achieve instructional objectives in history classroom. Conclusively there is an insignificant influence of counseling service upon students' abilities to resolve the difficulties in learning 2010 Post-Basic history curriculum in Katsina Zonal Education Quality Assurance, because about $0.4 \%$ of the entire changes in students' abilities to resolve their difficulties in learning 2010 Post-Basic history curriculum is determined by services of school counseling master. Therefore, the null hypothesis one is accepted at 0.05 significant levels. Also there is an insignificant influence of counseling service on teachers' abilities to resolve the instructional challenges in implementing Post-Basic history curriculum, because about $\mathrm{I} . \mathrm{I} \%$ of the entire changes in teachers' abilities to resolve their challenges to effective implementation of 2010 senior secondary history curriculum are resulted by the services of school counseling masters. The null hypothesis two is accepted at 0.05 significant levels. 


\section{References}

Alkammawa, A. U., \& Sambo, Z. S. (20I7). Challenges and Consequences of Becoming a Historian in Some Institutions of Nigeria. In Yandaki, I. A., \& Yasin, A. (Ed). (2017). The Consequences of Being a Historian: Thoughts and Reflections of Practitioners and students of History. Usmanu Danfodio University Press, Sokoto : Nigeria.

Department for Education. (2016). Counselling in schools: A blueprint for the future Departmental advice for school leaders and counselors. Department for Education: Britain.

Eyo, M. B. Joshua, A. M. and Esuong, A. E.(2010). Attitude of Secondary School Students Towards Guidance and Counselling Services in Cross River State, Edo Journal of Counselling Vol. 3, (I), 87 - 88.

Esebede, P., O. (2003). Reflections on History: Nationbuilding and the Nigerian University. The 2013 Inaugural Lecture, University of Nigeria Nsukka, Ibadan: Nigeria.

Espie, I. (1969), History in West African Secondary Schools. In Ade J.F., \& Espie, I. (Ed). (1969). Thousand Years of West African History: a Handbook For Teachers And Students. Nelson and Ibadan University Press, Ibadan: Nigeria.

Espie, I. (1969), History in West African Secondary Schools. in Ade J.F. and Espie, I. (Ed). (1969). Thousand Years of West African History: a Handbook For Teachers And Students. Nelson and Ibadan University Press, Ibadan: Nigeria. In Mohammed, Y. D. (20I7). UMYU Lecturers' and Students' Perception of History as an Instrument for Nation-Building in Nigeria, M. Ed Dissertation in Department of Education, Faculty of Education Umaru Musa Yar'adua University, Katsina.

Federal Republic of Nigeria. (2013). National Policy on Education (6 $6^{\text {th }}$ Ed). Nigerian Education Research Development Council. Lagos: Nigeria.

Federal Ministry of Education, (2019). Guideline for the Implementation of History Curriculum. National Educational Research and Development Council, Abuja: Nigeria.

Ignou, (20II). Introduction to Guidance and Counseling, Unit I: Understanding Guidance and Counseling. School of Education, Indira Gandhi National Open University, India.

Ihenetu, K. A. (20I3). Utilizing The School Curriculum To Achieve National Unity In Nigeria. In Nigerian Journal of Professional Teachers, 3 (I), 123 - 133.

Mohammed, Y. D., Muhammad B. and Abubakar, A. (20I8). Prospects of ICT as Innovation in Senior Secondary History Curriculum for Sustainable Development in Nigeria. FUDMA Journal of Educational Foundations (FUJEF), I, (I), 49 - 58.

Modo, F.; Sanni, K.; Uwah, C. \& Mogbo, I. (20I3). Guidance and Counseling Services in Secondary School as Coping Strategy for Improved Academic Performance of Students in Akwa Ibom State, Nigeria. Journal of Research on Humanities and Social Sciences, 3 (4), pp.43-47. In
Oguzie, S. N. (20/4). Guidance and Counselling Services as a Coping Strategy for Inculcating the Consciousness of Peace, Conflict Resolution and National Security among Secondary School Youths in Anambra State, Nigeria. African Research Review: An International Multidisciplinary Journal, Ethiopia Vol. 8 (2), Serial No. 33, April, 20/4:257,

http://dx.doi.org/10.4314/afrrev.v8i2.15,

Accessed on $24^{\text {th }}$ December, 2019, 2:36 pm.

Oguzie, S. N. (20|4). Guidance and Counselling Services as a Coping Strategy for Inculcating the Consciousness of Peace, Conflict Resolution and National Security among Secondary School Youths in Anambra State Nigeria. African Research Review: An International Multidisciplinary Journal, Ethiopia Vol. 8 (2), Serial No. 33, April, 20/4:257,

http://dx.doi.org//0.43/4/afrrev.v8i2.15, Accessed on $24^{\text {th }}$ December, 2019, 2:36 pm.

Oseiwu, A. H. (20|4). Career/Vocational Guidance/Counselling: A Tool For Functional Education And Graduate Employability. International Journal of Education and International Journal of Education and Practice 20/4 Vol. 2, No. 10, pp. 234-242.

Waisu, I. (2017). The Phobia of Studying History Among Students of Umaru Musa 'Yar Adua University, Katsina. In 'Yandaki, I.A., \& Yasin. A. (Eds). (20I7). The Consequences of Being $a$ Historian: Thoughts and Reflections of Practitioners and students of History. Usmanu Danfodio University Press, Sokoto : Nigeria.

Yusuf, M. D. and Mukhtar, B. (2018). ValueOrientation of History Curriculum for National Integration in Nigeria: Perception of UMYU Lecturers and Students. UMYU Journal of Educational Research. A Journal of the Faculty of Education, Umaru Musa Yar'dua University, 9 (I), 